\title{
OPTIMALISASI PEMBERDAYAAN PEREMPUAN DALAM KEPEMIMPINAN EFEKTIF
}

\author{
Rini Puji Astuti \\ Fakultas Ekonomi dan Bisnis Islam IAIN Jember \\ rinipuji.astuti99@gmail.com
}

\begin{abstract}
The challenge in dealing changes and demands in coming era is the rapid change of dynamic times. So that, the role of women is needed in dealing an existing problems in society, such as many social problems that occur in the society. therefore, need a leader who is reliable and resilient. Today, women's leadership is still being debated because some Muslim societies are viewed cynically, even though it has long been found that women bave succeeded in being the subject of achieving leadership goals, for example in development, so the term "Women's Leadership" is no longer suitable to used, because the more suitable is "Optimizing the Empowerment of Women's Leadership". One example in the Jokowi-JK government has been to appreciated the role of women in strategic positions than the previous government. There are eight women ministers in Jokowi government, namely Rini Soemarno (Minister of State-Owned Enterprises), Siti Nurbaya (Minister of Forestry and Environment), Puan Mabarani (Coordinating Minister for Human Development and Culture), Nila F Moeloek (Minister of Health), Khofifah Indar Parawansa (Minister of Social Affairs), Yohana Yembise (Minister of Women's Empowerment and Child Protection), Retno LP Marsudi (Minister of Foreign Affairs), and Susi Pudjiastuti (Minister of Maritime Affairs and Fisheries), as well as nine KPK panelists who are women. they can show achievements according to their duties and responsibilities. So far, women's efforts still face many obstacles or challenges. These obstacles or challenges start from external factors and internal factors. In addition, the role of women is needed in the family, this is an asset of the nation that makes the next generation to build a developed, fair, and prosperous country.
\end{abstract}

Keywords: Optimizing Women's Empowerment, Effective Leadership 


\section{Rini Puji Astuti}

\section{Abstrak}

Tantangan dalam menghadapi perubahan dan tuntutan di era mendatang adalah perubahan jaman yang dinamis. Oleh karena itu diperlukan peran perempuan dalam menghadapi permasalahan yang ada di masyarakat, seperti berbagai permasalahan sosial yang terjadi di masyarakat. Oleh karena itu dibutuhkan seorang pemimpin yang handal dan tangguh. Kepemimpinan perempuan saat ini masih diperdebatkan karena sebagian masyarakat muslim dipandang sinis, padahal sudah lama ditemukan bahwa perempuan telah berhasil menjadi subjek pencapaian tujuan kepemimpinan, misalnya dalam pembangunan, sehingga istilah "Kepemimpinan Perempuan" tidak ada. lagi cocok dipakai, karena yang lebih cocok adalah "Mengoptimalkan Pemberdayaan Kepemimpinan Wanita". Salah satu contoh dalam pemerintahan Jokowi-JK adalah mengapresiasi peran perempuan pada posisi-posisi strategis dibanding pemerintahan sebelumnya. Ada delapan menteri perempuan di pemerintahan Jokowi, yakni Rini Soemarno (Menteri Badan Usaha Milik Negara), Siti Nurbaya (Menteri Kehutanan dan Lingkungan Hidup), Puan Maharani (Menteri Koordinator Pembangunan Manusia dan Kebudayaan), Nila F Moeloek (Menteri Kesehatan). ), Khofifah Indar Parawansa (Menteri Sosial), Yohana Yembise (Menteri Pemberdayaan Perempuan dan Perlindungan Anak), Retno LP Marsudi (Menteri Luar Negeri), dan Susi Pudjiastuti (Menteri Kelautan dan Perikanan), serta sembilan orang Panelis KPK yang perempuan. mereka dapat menunjukkan prestasi sesuai dengan tugas dan tanggung jawabnya. Selama ini upaya perempuan masih menghadapi banyak kendala atau tantangan. Hambatan atau tantangan tersebut dimulai dari faktor eksternal dan faktor internal. Selain itu, peran perempuan sangat dibutuhkan dalam keluarga, hal ini merupakan aset bangsa yang menjadikan generasi penerus bangsa untuk membangun negara yang maju, adil, dan sejahtera.

\section{Kata Kunci : Komodifikasi, Jilbab, Sejarah Peradaban Manusia}

\section{Pendahuluan}

Kepemimpinan adalah faktor penting dalam menciptakan tatanan sosial yang lebih baik. Oleh sebab itu, semua manusia memiliki peran dan tanggung jawab kepemimpinan secara bersama-sama. Dikarenakan ruang lingkup kepemimpinan terletak pada tanggungjawab bagi setiap manusia atau tugas-tugasnya di bumi Allah SWT dalam lapangan dan sektor yang beragam. Inti dari 
Vol. 12, No. 2, Oktober 2019

p-ISSN:2086 -0749

e-ISSN:2654-4784

kepemimpinan terletak pada tugas seseorang untuk menegakkan kebenaran dan keadilan. Bukan hanya dikarenakan kekuasaan yang kebanyakan berujung pada melimpah fasilitas dan melimpah akses kebijakan secara cepat dan mudah. Maka, kepemimpinan bukan saja tugas laki-laki, akan tetapi juga kaum perempuan. ${ }^{1}$

Perempuan juga memiliki peran dan tanggung jawab kepemimpinan dalam setiap tingkatan di manapun. Setiap manusia bisa menjadi pemimpin dalam tingkatan apapun, baik sebagai pemimpin pemerintahan, instansi, maupun masyarakat. Bahkan, juga dapat menjadi pemimpin perang sekalipun, tanpa melihat jenis kelamin laki-laki atau perempuan. ${ }^{2}$ Kepemimpinan perempuan tidak

\footnotetext{
1 Nurul, Kepemimpinan Perempuan (Yogyakarta: Penerbit Andi, 2008), 65.

2 Mubin, Gaya Kepemimpinan Persamaan Gender (Yogyakarta: Penerbit Andi, 2008), 65-66.
}

hanya terbatas dalam kehidupan rumah tangga, tetapi juga dalam masyarakat. Kepemimpinannya tidak hanya dalam batasan upaya mempengaruhi kaum laki-laki agar mengakui hak-haknya yang sah, akan tetapi juga harus mencakup sesama gender agar dapat maju bekerja sama meraih dan memelihara harkat dan martabat mereka, serta menampung setiap upaya dari siapapun, baik laki-laki maupun perempuan, komunitas kecil atau besar yang memiliki tujuan mengarahkan mereka ke arah yang bertentangan dengan harkat dan martabatnya. Peran domestik perempuan yang sifatnya kodrati seperti hamil, melahirkan, menyusui, dan lain-lain, memang tidak mungkin digantikan oleh laki-laki. Akan tetapi, dalam peran di masyarakat, perempuan sebagai anggota masyarakat dan atau sebagai warga negara, mempunyai hak untuk 


\section{Rini Puji Astuti}

mengemukakan pendapat, berpolitik, dan melakukan peran sosialnya yang lebih tegas dan transparan.

\section{Temuan Penelitian dan}

\section{Pembahasan}

\section{Tipe dan Gaya Kepem- impinan Efektif}

Pemimpin diartikan sebagai seseorang yang dapat mempengaruhi orang lain dan memiliki otoritas manajerial. Kepemimpinan yaitu apa yang dilakukan pemimpin. Kepemimpinan adalah proses memimpin sebuah kelompok dan mempengaruhi kelompok itu untuk mencapai tujuan yang diharapkan. Dalam teori-teori awal kepemimpinan berfokus pada pemimpin (teori sifat) dan bagaimana upaya pemimpin berinteraksi dengan anggota kelompoknya (teori perilaku). Teori sifat (trait theories) berdasarkan fokus dan riset kepemimpinan pada tahun 1920-an dan 1930-an terletak dalam menyelami sifat pemimpin yaitu, karakteristik yang dapat membedakan antara pemimpin dan non pemimpin. Sifatsifat dipelajari adalah fisik, penampilan, golongan sosial, stabilitas emosi, kelancaran berbicara, dan kemampuan bersosial dalam hubungan bermasyarakat.

Dengan memiliki sifat yang tepat, maka kemungkinan besar seorang individu dapat menjadi seorang pemimpin yang efektif. Berikut ini tujuh sifat yang berkaitan dengan kepemimpinan yang efektif:

a. Penggerak (drive). Pemimpin menunjukkan tingkat usaha yang tinggi. Mereka memiliki keinginan yang relatif tinggi terhadap keberhasilan, ambisius, memiliki banyak semangat, tidak kenal lelah dalam aktivitasnya, dan menunjukkan kinerja.

b. Hasrat untuk memimpin (desire to lead). Pemimpin memiliki hasrat yang kuat untuk 
Vol. 12, No. 2, Oktober 2019

p-ISSN:2086 -0749

e-ISSN:2654-4784

mempengaruhi dan memimpin orang lain. Mereka menunjukkan kemauan untuk menerima tugas dan tanggung jawab.

c. Kejujuran dan integritas (bonesty and integrity). Pemimpin membangun hubungan terpercaya dengan bawahannya dengan cara jujur dan tidak menghianati, dan selalu menjaga konsistensi antara katakata dan perbuatannya.

d. Kepercayaan diri (self confidence). Pemimpin harus dapat menunjukkan kepercayaan diri agar dapat meyakinkan pengikutnya terhadap keputusan dan tujuan yang harus dicapai.

e. Kecerdasan (intelligence). Pemimpin harus cukup cerdas agar dapat mengumpulkan, menyatukan, dan menerjemahkan banyak informasi, dan mereka harus dapat menciptakan visi, memecahkan permasalahan, dan mengambil keputusan yang tepat.

f. Pengetahuan yang relevan mengenai pekerjaan (jobrelevant knowledge). Pemimpin yang efektif memiliki pengetahuan tingkat tinggi mengenai perusahaan, industri, dan permasalahan teknis. Dengan pengetahuan yang mendalam, pemimpin dapat membuat kebijakan terbaik dan memahami implikasi kebijakan tersebut.

g. Extraversion. Pemimpin adalah orang yang penuh semangat. Suka bergaul, tegas, dan jarang sekali berdiam atau menarik diri.

Berikut ini empat gaya kepemimpinan menurut Hersey dan Blanchard: 


\section{Rini Puji Astuti}

a. Telling (pekerjaan tinggirelasi rendah), yaitu pemimpin menentukan peranan karyawan dan mengatur apa, kapan, bagaimana, dan dimana karyawan melaksanakan tugasnya.

b. Selling (pekerjaan tinggirelasi tinggi), yaitu pemimpin menunjukkan perilaku yang mengarahkan dan mendukung.

c. Participating (pekerjaan rendah relasi tinggi), yaitu pemimpin dan pengikutnya bersamasama membuat keputusan, di mana pemimpin memiliki peranan sebagai fasilitator dan komunikator.

d. Delegating (pekerjaan rendah relasi rendah), yaitu pemimpin kurang memberikan pengarahan atau dukungan.

\section{Komunikasi}

dalam

Pengembangan Kepemimpinan Efektif

Kepemimpinan yang dikatakan efektif membutuhkan komunikasi kepada bawahannya dengan baik. Dalam hal ini berorganisasi adalah hasil interaksi antar perorangan dan kelompok dalam organisasi. Berorganisasi adalah hasil hubungan antar perseorangan dan kelompok dalam organisasi, dan semuanya akan mempengaruhi hubungan dalam organisasi tersebut di masa yang akan datang.

Salah satu persyaratan kepemimpinan yang efektif adalah adanya kemampuan untuk andil dalam mengambil kebijakan. Dalam hal ini diperlukan adanya keberanian dan penggunaan kesempatan yang didukung oleh kemampuan serta kemauan perempuan itu sendiri, kepemimpinan perempuan dalam bidang kehidupan keseharian tidak banyak bermanfaat. $^{3}$

\section{Peran Perempuan dalam} Kepemimpinan

3 Tan, Kepemimpinan Perempuan yang Efektif (Yogyakarta: 1996), 29. 
Vol. 12, No. 2, Oktober 2019

p-ISSN:2086 -0749

e-ISSN:2654-4784

Dalam penekanan peran gender serta peran pemimpin, peran teori sosial berpendapat bahwa pemimpin menempati peran yang didefinisikan pada posisi mereka yang spesifik dalam hierarki dan sekaligus berfungsi di bawah kendala peran gender mereka. Dalam hal definisi umum peran sosial sebagai harapan yang berlaku untuk orang yang menempati posisi sosial tertentu dalam masyarakat atau anggota pada kelompok tertentu dimana pada kategori sosial sangat dibutuhkan dalam masyarakat sebagai makhluk sosial.

Peran gender adalah keyakinan konsensual tentang atribut perempuan dan laki-laki. Jika jumlah perempuan lebih banyak dalam proses pengambilan keputusan, maka fokus kehidupan poli-

\footnotetext{
${ }^{4}$ Sarbin \& Allen dalam Eagly et al., buku Sosial (Yogyakarta: 2003), 95.
}

tik juga akan berubah. Dampak yang paling jelas adalah akan terjadinya perluasan wilayah politik ke arah masalah-masalah dan isuisu yang semula dianggap bukan isu politik seperti kesejahteraan anak, perlindungan terhadap reproduksi perempuan, dan lainlain. Kehidupan politik barangkali juga akan lebih bermoral karena perempuan lebih mementingkan isu politik konvensional seperti ekonomi, pendidikan, perumahan, lingkungan, kesejahteraan sosial.

\section{Teknik Kepemimpinan}

Teknik kepemimpinan yaitu komunikasi dimana secara tegas menekankan begitu pentingnya peran dalam berbagi tujuan dan visi. Agar berbagi tujuan dan visi melalui komunikasi, kepercayaan antara pemimpin dan pengikut dibutuhkan untuk berkomitmen pada visi pemimpin. Dan bisa memberikan motivasi pada orang 


\section{Rini Puji Astuti}

lain. Ada delapan teknik agar kepemimpinan efektif melalui komunikasi, diantaranya:

a. Membentuk tujuan

b. Membuat tujuan sebagai tujuan tim

c. Memperlakukan orang lain seperti dirinya

d. Membuat masing-masing anggota bertanggung jawab untuk produk tim

e. Berbagai kemuliaan

f. Mengambil setiap kesempatan untuk membangun kepercayaan diri tim

g. Terlibat dalam setiap kegiatan

h. Menjadi mentor

i. Tindak tanduk seorang pemimpin sebaiknya:

j. Memposisikan diri pada posisi orang lain

k. Memperlakukan pegawai seperti kolega, tidak merendahkan diri, mendikte atau mencaci maki

1. Mengikutsertakan orang lain

m. Memperlakukan sebagai organisasi baik besar dan kecil n. Memberi penghargaan, pujian, dan rewards.

Dalam hal ini, prinsip pengakuan merefleksikan kepercayaan Carnegie bahwa "orang pergi bekerja untuk uang, tetapi pergi ekstra mill untuk pengakuan, pujian, dan rewards. Carnegie percaya bahwa pegawai yang baik dapat ditransformasikan ke dalam orang yang hebat melalui motivator yang powerful, saling menghormati.

Teknik sikap positif, membentuk sikap mental positif, prinsip ini diinspirasi oleh quote dari Marcus Aurelius "kehidupan kita adalah apa yang pikiran kita buat". Pemimpin yang mengadopsi pendekatan ideologi cenderung untuk mengikutsertakan perilaku positif untuk membentuk iklim berkelanjutan sebuah relasi oleh norma kolaboratif. Pemeliharaan sikap positif adalah aspek yang penting dari kepemimpinan ideologi yang penting terhadap kemampuan 
Vol. 12, No. 2, Oktober 2019

p-ISSN:2086 -0749

e-ISSN:2654-4784

pemimpin untuk mempromosikan nilai yang berkelanjutan.

\section{Kepemimpinan dalam}

\section{Keluarga}

Adalah kepemimpinan oleh perempuan dititikberatkan peran seorang Ibu di dalam sebuah keluarga yang bertanggung jawab dari segala urusan anggota keluarga dan keadaan rumahnya, sampai pada keadaan pengurusan di luar rumah. Pada dasarnya seorang pemimpin haruslah memiliki bobot kepemimpinan dengan perilaku positif dan memiliki kelebihan-kelebihan tertentu antara lain:

a. Beriman dan bertaqwa kepada Allah.

b. Kelebihan jasmani dan rohani.

c. Berani, terampil, dan berpengetahuan.

d. Adil, jujur, bijaksana, dan demokratis. e. Penyantun, paham keadaan ummat.

f. Ikhlas berkurban, qana'ah dan istiqamah.

Indikator dari kepemimpinan dapat ditandai oleh beberapa ciri sebagai berikut: ${ }^{5}$

a. Kapasitas, seperti kecerdasan, kewaspadaan, kemampuan berbicara atau verbal facility, kemampuan menilai.

b. Prestasi, seperti gelar kesarjanaan, ilmu pengetahuan, perolehan dalam olahraga.

c. Tanggung jawab, seperti mandiri, berinisiatif, tekun, ulet, percaya diri, agresif, dan punya hasrat untuk unggul.

d. Partisipasi, seperti aktif memiliki sociability yang tinggi, mampu bergaul, suka bekerja sama,

${ }^{5}$ Ralp M. Stogdill dalam "Personil Factor Associated With Leadership” yang dikutip oleh James A. Lee dalam bukunya "Management Theories and Prescriptions", 70. 


\section{Rini Puji Astuti}

mudah menyesuaikan diri, dan punya rasa humor.

e. Tingkatan yang meliputi kedudukan sosial ekonomi yang cukup tinggi, popular dan ketenaran.

\section{Konsep Kepemimpinan}

Konsep kepemimpinan menurut Ki Hajar Dewantara meliputi: "Ing Ngarso Sung Tuladha, Ing Madyo Mangun Karsa, Tut Wuri Handayani". Secara harfiah dapat diartikan sebagai berikut, "Di depan menunjukkan contoh, di tengah memberikan semangat, di belakang menunjukkan dorongan". Konsep yang sudah berumur puluhan tahun ini ternyata masih relevan diterapkan dalam gaya kepemimpinan saat ini.

a. Ing Ngarso Sung Tuladha

Seorang pemimpin harus dapat menjadi model yang dapat dicontoh oleh pengikutnya. Dan harus berdiri di depan dalam memberikan contoh nyata agar dapat diikuti oleh bawahannya. Seorang pemimpin harus mampu menguasai bidang pekerjaannya. Selain dari sisi pengetahuan teknis, kematangan pribadi dan sikap harus diperhatikan karena tingkah laku sang pemimpin selalu menjadi perhatian bawahannya. Baik dari sisi moral dan akhlak, pergaulan, bahkan kehidupan keluarganya pun akan menjadi panutan bagi bawahannya.

b. Ing Madya Mangun Karsa

Membangun motivasi dan semangat berkarya adalah salah satu tugas seorang pemimpin. Selain harus mampu membaca situasi dan keadaan perusahaannya, pemimpin yang baik harus dapat mengelola SDM yang dimilikinya agar dapat bekerja secara optimal. Membangun semangat kebersamaan (team building) dan mengkomunikasikan kepada seluruh karyawan tentang visi, misi, dan nilai-nilai perusahaan adalah hal wajib bagi pemimpin. Sampaikan target dan sasaran utama dan langkah apa yang akan 
Vol. 12, No. 2, Oktober 2019

p-ISSN:2086 -0749

e-ISSN:2654-4784

dijalankan, dan ajak seluruh karyawan untuk mencapainya. Dengan membangun rasa kekeluargaan dan rasa memiliki perusahaan, diharapkan seluruh karyawan akan bekerja sekuat tenaga dan berhati-hati.

c. Tut Wuri Handayani

Memberikan dorongan semangat motivasi dan memfasilitasi kebutuhan bawahannya untuk mencapai target akan sangat dihargai oleh karyawannya. Bagaimanapun yang paling sering turun ke lapangan dan bertemu dengan customer adalah para karyawan atau bawahan. Cukupi kebutuhannya, berdayakan mereka dan beri bekal dalam bentuk pelatihan. Jika karyawan sudah mampu menjalankan tugas dengan baik dan sesuai visi perusahaan, tentu target dan sasaran kerja dapat dicapai dengan maksimal.

\section{Tipe-Tipe Kepemimpi-}

nan

Dalam prakteknya, tipe kepemimpinan ini sangat bervariasi dan terdapat banyak pendapat dan tinjauan tentang tipe kepemimpinan tersebut. Meskipun belum ada komitmen mengenai tipe kepemimpinan yang secara luas dikenal dewasa ini, terdapat lima tipe kepemimpinan yang umum digunakan, yaitu:

a. Tipe Karismatik

Dalam Kamus Besar Bahasa Indonesia (KBBI) diartikan bahwa "kharismatik bersifat karisma". Sedang perkataan karisma diartikan sebagai keadaan atau bakat yang dihubungkan dengan kemampuan yang luar biasa dalam hal kepemimpinan seseorang untuk mempengaruhi berlebihan dan rasa kagum dari masyarakat terhadap dirinya. Karisma dapat juga diartikan atribut kepemimpinan 


\section{Rini Puji Astuti}

yang didasarkan atas kualitas kepribadian individu. ${ }^{6}$

Tipe karismatik ini diwarnai oleh indikator sangat besarnya pengaruh sang pemimpin terhadap para pengikutnya. Kepemimpinan seperti ini lahir karena pemimpin tersebut mempunyai kelebihan yang bersifat psikis dan mental serta kemampuan tertentu, sehingga apa yang diperintahkannya akan dituruti oleh pengikutnya. Biasanya dalam kepemimpinan karismatik ini interaksi dengan lingkungan lebih banyak bersifat informal, karena dia tidak perlu diangkat secara formal dan tidak ditentukan oleh kekayaan, tingkat usia, bentuk fisik, dan sebagainya. Meskipun demikian, kepercayaan terhadap dirinya sangat tinggi dan para pengikutnya pun mempercayainya dengan penuh kesungguhan, sehingga dia sering dipuja dan dipuji bahkan diagungkan. Sebab dalam kesehar- iannya dengan kewibawaannya yang cukup besar, dia mampu menggerakkan pengikutnya tanpa memerlukan dari pihak lain.

b. Tipe Paternalistik

Tipe kepemimpinan paternalistik berorientasi pada penyelesaian tugas (result oriented) serta memelihara komunikasi dan hubungan baik dengan bawahannya (hubungan antara bapak dengan anak-anaknya), sehingga tipe ini sering disebut dengan tipe kepemimpinan yang kebapakan, dengan sifat-sifat antara lain sebagai berikut:

1) Menganggap bawahannya sebagai manusia yang tidak/belum dewasa, atau anak sendiri yang perlu dikembangkan

2) Bersikap terlalu melindungi (overly protective)

3) Jarang memberikan kesempatan kepada bawahan untuk mengambil keputusan sendiri

\footnotetext{
${ }^{6}$ Nawawi, Tipe Kepemimpinan (Yogyakarta: 1993), 103.
} 
Vol. 12, No. 2, Oktober 2019

p-ISSN:2086 -0749

e-ISSN:2654-4784

4) Minim sekali memberikan kesempatan kepada bawahan untuk berinisiatif

5) Minim sekali bahkan hampir tidak pernah memberikan kesempatan kepada bawahan untuk mengembangkan imajinasi dan daya kreativitas mereka sendiri

6) Selalu bersikap selalu tahu dan selalu benar.

c. Tipe Militeris

Tipe kepemimpinan militeris ini dapat dikatakan sifatnya militeran. Hanya gaya luarnya saja yang mencontoh gaya militer. Tetapi jika dilihat lebih seksama, tipe ini mirip sekali dengan tipe kepemimpinan otoriter. Hendaknya dipahami, bahwa tipe kepemimpinan militeris itu berbeda sekali dengan kepemimpinan organisasi militer (seorang tokoh militer). Adapun sifat-sifat pemimpin yang militeris antara lain:
1) Lebih banyak menggunakan sistem perintah/komando terhadap bawahannya, keras, otoriter, kaku, dan seringkali kurang bijaksana.

2) Menghendaki kepatuhan mutlak dari bawahan.

3) Sangat menyenangi formalitas, upacara-upacara ritual, dan tanda tanda kebesaran yang berlebihan.

4) Menuntut adanya disiplin tinggi dan kaku dari bawahannya.

5) Tidak menghendaki, saran, usul, sugesti, dan kritikankritikan dari bawahannya.

6) Komunikasi hanya berlangsung searah saja.

d. Tipe Otokratis

Tipe kepemimpinan otokratis atau otoriter menempatkan kekuasaan di tangan pemimpin (penguasa tunggal). Posisi bawahan hanya sebagai pelaksana kepu- 


\section{Rini Puji Astuti}

tusan, perintah, dan bahkan pelaksana apa yang diinginkan pimpinan. Pemimpin memandang dirinya tidak memiliki kelemahan dan kekurangan. Potensi yang dimiliki bawahannya dianggap rendah, sehingga mereka dipandang tidak mampu berbuat apa-apa. ${ }^{7}$ Dalam proses pengambilan keputusan, pemimpin yang memiliki tipe kepemimpinan otokratis tidak melibatkan orang lain atau bawahannya, melainkan bertindak sendiri. Bawahannya hanya diharapkan melaksanakan keputusan yang telah diambil oleh pemimpinnya. Dalam berkomunikasi atau menjalin hubungan dengan bawahannya, pemimpin dengan tipe ini menggunakan pendekatan formal sesuai dengan jabatan, tugas serta tanggung jawabnya.

Adapun sifat-sifat yang dimiliki pemimpin dengan tipe kepemimpinan otokratis antara lain:

7 Torang, Tipe Kepemimpinan (Yogyakarta: 2013), 66.
1) Minim mempercayai bawahan/anggota kelompoknya

2) Bersikap otoriter

3) Beranggapan hanya dengan imbal jasa materi sajalah yang mampu mendorong orang untuk bertindak

4) Minim toleransi terhadap kesalahan yang dilakukan bawahan/anggota kelompok

5) Peka terhadap perbedaan kekuasaan

6) Minim perhatian kepada bawahan/anggota kelompoknya

7) Memberikan kesan seolah-olah demokratis

8) Mendengarkan pendapat bawahan/anggota kelompoknya semata-mata hanya untuk menyenangkan

9) Senantiasa membuat keputusan sendiri.

e. Tipe Demokratis

Tipe kepemimpinan demokratis dalam organisasi menempatkan bawahan sebagai faktor utama dan terpenting. Seorang pemimpin menempatkan 
Vol. 12, No. 2, Oktober 2019

p-ISSN:2086 -0749

e-ISSN:2654-4784

bawahannya sebagai subjek yang memiliki keinginan, kebutuhan, kemampuan, pendapat, kreativitas, dan inisiatif yang berbeda-beda dan harus dihormati. Tipe kepemimpinan demokratis mengindikasikan kepemimpinan yang aktif, dinamik, dan terarah.

Dalam mengambil keputusan, tipe demokratis selalu mengedepankan musyawarah. Kepemimpinan demokratik adalah tipe kepemimpinan yang paling ideal untuk dikembangkan dalam organisasi yang modern. Pertimbangannya adalah karena lebih cocok dengan fitrah manusia dan mudah untuk diterapkan dalam semua lapisan, baik masyarakat desa maupun masyarakat kota.

Secara filosofis, corak kepemimpinan demokratis akan tergambar dalam tindakan dan perilaku pemimpinnya, antara lain sebagai berikut:
1) Pemimpin secara menyeluruh tidak membedakan bawahannya

2) Pengambilan keputusan sangat berorientasi kepada keputusan kelompok, bukan hasil pemikiran dari seorang pemimpin saja

3) Pola dialog menjadi kebutuhan dalam menumbuhkan inisiatif kelompok

4) Tugas dan wewenang disesuaikan dengan ruang lingkup pekerjaan yang tersedia

5) Memberi peluang yang luas kepada bawahan untuk berkembang sesuai dengan nya

6) Selalu mengatakan bahwa keberhasilan yang dicapai adalah keberhasilan bersama (kelompok).

\section{Sifat-Sifat Pemimpin}

Dalam kepemimpinan Islam menawarkan konsep tentang per- 


\section{Rini Puji Astuti}

ilaku seorang pemimpin sebagaimana yang terdapat dalam pribadi para Rasul. Yang mana kepemimpinan Nabi/Rasul ditunjang dengan sifat-sifat terpuji. Adapun sifat-sifat para Nabi dan Rasul adalah ;1). Jujur (shiddiq), 2). Dapat dipercaya (amanab), 3). Menyampaikan (tabligh), 4).Cerdas (fathanab). Sifat/karakteristik di atas dijelaskan sebagai berikut:

\section{a. Shiddiq}

Adalah sifat/karakteristik Nabi Muhammad SAW yang berarti benar dan jujur dalam sepanjang kepemimpinannya. Benar dalam mengambil keputusankeputusan yang menyangkut visi dan misi, efektif dan efisien dalam implementasi serta operasionalnya di lapangan.

\section{b. Amanah}

Amanah artinya dapat dipercaya, bertanggung jawab, dan credible. Amanah juga bisa bermakna keinginan untuk memenuhi sesuatu dengan ketentuan amanah juga berarti memiliki tanggung jawab dalam melaksanakan tugas dan kewajiban yang diberikan kepadanya. Sifat/karakteristik amanah ini akan membentuk kredibilitas yang tinggi dan sikap penuh tanggung jawab pada setiap individu muslim.

c. Tabligh

Sifat/karakteristik tabligh artinya komunikatif dan bisa bekerjasama. Orang yang memiliki sifat tabligh, akan menyampaikannya dengan benar (berbobot) dan dengan tutur kata yang tepat (alhikmah) yang berarti berbicara dengan orang lain dengan suatu yang mudah dipahami dan diterima oleh akal, bukan berbicara yang sulit dimengerti.

d. Fathanah

Fathanah dapat diartikan sebagai intelektual, kecerdikan dan kebijaksanaan. Sifat/karakteristik ini dapat menumbuhkan kreatifitas dan kemampuan untuk melakukan berbagai macam inovasi yang bermanfaat. Pada dasarnya seorang pemimpin haruslah 
memiliki bobot kepemimpinan dengan perilaku positif dan kelebihan-kelebihan tertentu antara lain:

a) Beriman dan bertaqwa kepada Allah

b) Berani, terampil, dan berpengetahuan

c) Adil, jujur, bijaksana, dan demokratis

d) Penyantun, paham keadaan umat

e) Ikhlas berkurban, qana'ah dan istiqamah.

\section{Kepemimpinan Per- empuan}

Kepemimpinan diartikan sebagai suatu cara dan metode seseorang yang dapat mempengaruhi orang lain sedemikian rupa sehingga orang tersebut dengan sadar mengikuti dan mematuhi segala kehendak-
Nya. ${ }^{8}$ Perempuan diartikan sebagai makhluk tertentu yang diciptakan oleh Allah SWT yang memiliki ciri menstruasi, mengandung, melahirkan dan menyusui. ${ }^{9}$ Dari pendapat di atas dapat disimpulkan bahwa kepemimpinan perempuan adalah suatu cara atau metode yang dilakukan oleh jenis manusia ciptaan Allah SWT yang memiliki ciri-ciri menstruasi, mengandung, melahirkan, dan menyusui yang dapat mempengaruhi orang lain sedemikian rupa sehingga orang tersebut dengan sadar mengikuti dan mematuhi segala kehendaknya. Kata kunci kepemimpinan terletak pada tugas seseorang untuk menegakkan kebenaran dan keadilan. Bukan semata-mata kekuasaan yang ke-

\footnotetext{
${ }^{8}$ Joewono, Kepemimpinan (Yogyakarta: 2002), 2.

9 Abdul Qadhir Mansyur, Kepemimpinan Perempuan (Yogyakarta: 2005), 22-23.
} 


\section{Rini Puji Astuti}

banyakan berujung pada kemudahan fasilitas dan kemudahan mengakses kebijakan secara cepat dan mudah.

Dalam peran publik ini, menurut Islam diperbolehkan melakukan peran-peran tersebut dengan konsekuensi bahwa ia dapat dipandang mampu dan memiliki kapasitas untuk menduduki peran-peran itu. Dalam peran publik, perempuan memiliki berbagai aktivitas yang bersifat peran sosial, budaya, politik, ekonomi, dan sebagainya. Dalam ranah domestik, yaitu urusan rumah tangga, bukan hanya kaum laki-laki saja yang menjadi pemimpin, kaum perempuan pun juga memiliki tugas memimpin urusan rumah tangganya. Sebagaimana hadits Rasulullah SAW:

"Setiap manusia keturunan Adam adalab kepala, maka seorang pria adalah kepala keluarga, sedangkan wanita adalab kepala rumah tangga" (HR. Abu Hurairah)
Pandangan mengenai persamaan hak antara laki-laki dan perempuan juga gencar disuarakan oleh kaum feminis. Perspektif Feminis terdiri dari beberapa tingkatan, yaitu Feminisme Liberal, Feminisme Marxis, Feminisme Radikal, dan Feminisme Sosialis. Golongan Feminisme Liberal mengasumsikan bahwa kebebasan dan keseimbangan berakar pada rasoinalitas. Pada dasarnya tidak ada perbedaan antara laki-laki dan perempuan. Oleh karena itu, dasar perjuangan mereka adalah menuntut kesempatan dan hak yang sama bagi setiap individu termasuk perempuan atas dasar kesamaan keberadaannya sebagai makhluk rasional. Sementara kehidupan tradisional ditandai dengan karakter yang sebaliknya. Nilai-nilai tradisional inilah yang menyebabkan perempuan tidak bisa bersaing secara adil dengan laki-laki, karena potensi perempuan dibatasi dari dunia publik yang senantiasa produktif 
Vol. 12, No. 2, Oktober 2019

p-ISSN:2086 -0749

e-ISSN:2654-4784

dan dinamis. Aturan yang adil adalah dengan membebaskan perempuan dalam seluruh aspek kehidupan dan menyejajarkannya dengan laki laki. ${ }^{10}$ Golongan Feminisme Liberal ini menghendaki agar perempuan diintegrasikan secara total di dalam semua peran, termasuk bekerja di luar rumah.

Feminisme Marxis berpendapat bahwa ketertinggalan yang dialami oleh perempuan bukan disebabkan oleh tindakan individu secara sengaja, tetapi akibat dari struktur sosial, politik, dan ekonomi yang erat kaitannya dengan sistem kapitalisme. Menurut mereka, tidak mungkin perempuan dapat memperoleh kesempatan yang sama seperti pria jika mereka masih tetap hidup dalam masyarakat yang berkelas. Fokus gerakan ini berkisar pada

10 Muslikhati, Kepemimpinan Perempuan dalam Peran Gender (Yogyakarta: 2004), 32. hal-hal yang berhubungan dengan pekerjaan perempuan, bagaimana pranata keluarga dikaitkan dengan sistem kapitalisme, bagaimana pekerjaan perempuan dalam mengurus rumah tangga tidak dianggap penting dan dianggap bukan pekerjaan, bagaimana para perempuan itu jika terjun dalam pasar tenaga kerja diberi pekerjaan yang membosankan dan memperoleh upah yang lebih rendah dibandingkan dengan pria. ${ }^{11}$

Feminisme Radikal berpendapat bahwa struktur masyarakat dilandaskan pada hubungan hierarkis berdasarkan jenis kelamin. Laki-laki sebagai suatu kategori sosial mendominasi kaum perempuan sebagai kategori sosial yang lain karena laki-laki diuntungkan dengan adanya subordinasi perempuan. Dominasi laki-

11 Ihromi, Kiprah Perempuan (Yogyakarta: 1995), 89. 


\section{Rini Puji Astuti}

laki atau subordinasi perempuan ini, menuntut mereka, merupakan suatu model konseptual yang bisa menjelaskan berbagai bentuk penindasan yang lain. Menurut aliran ini jenis kelamin seseorang adalah faktor yang paling berpengaruh dalam menentukan posisi sosial, pengalaman hidup, kondisi fisik dan psikologis, serta kepentingan dan nilai-nilainya. ${ }^{12}$

Feminisme

Sosialis

mengasumsikan bahwa hidup dalam masyarakat yang kapitalistik bukan satu-satunya penyebab utama keterbelakangan perempuan sebagai perempuan. Selain di negara negara kapitalis, di negaranegara sosialis, para perempuannya juga terjun dalam pasaran tenaga kerja dan sebagian besar secara ekonomi mereka sudah mandiri. Sedangkan kaum feminis Muslim secara umum sepakat bahwa sistem patriarki yang sudah begitu mengakar di masyarakat memang dipengaruhi

${ }^{12}$ Ihromi, Kiprab Perempuan, 87 oleh doktrin agama yang mengkoordinasikan perempuan di bawah superioritas laki-laki. Pandangan ini memang bisa jadi benar tetapi pada saat yang sama bisa juga salah. Sebab dalam tradisi doktrin

Islam sendiri, ide Al-Quran yang menjunjung tinggi persamaan laki-laki dan perempuan seringkali berbenturan dengan sifat ordiner masyarakat Islam yang cenderung bermacammacam. Al-Quran pada dasarnya memberikan justifikasi yang sangat jelas tentang kesejajaran antara laki-laki dan perempuan. Namun, pada kenyataannya kadangkala landasan normatif dan ideal ini berhadapan dengan realitas sejarah yang nyata berseberangan dengan Al-Quran.

Dalam dunia Islam, gerakan feminisme juga telah berkembang dan menjadi wacana bagi beberapa feminis Muslim. Feminis Muslim dunia seperti Rifaat Hassan, Fatima Mernissi, Nawal Sadawi, Ami- 
Vol. 12, No. 2, Oktober 2019

p-ISSN:2086 -0749

e-ISSN:2654-4784

na Wadud Muhsin, dan beberapa feminis Muslim dari Indonesia seperti Wardah Hafidz, Lies Marcoes Natsir, Siti Ruhaini, dan Nurul Agustina berusaha membongkar berbagai macam pengetahuan normatif yang bias kepentingan laki-laki, khususnya menyangkut relasi gender. Mereka menyadari bahwa banyak hukum agama, misalnya hukum personal keluarga, praktek keagamaan, dan termasuk pula soal keabsahan kepemimpinan sosial-politik apalagi keagamaan bagi perempuan, disusun berdasarkan asumsi patriarki.

Pusat persoalan-persoalan yang didiskusikan oleh para feminis Muslim adalah berbagai hukum yang oleh para ahli hukum klasik diklaim sebagai hukum yang dilandasi ayat-ayat tertentu dari Al-Quran. Kebanyakan yang didiskusikan dalam hal ini adalah hukum-hukum mengenai status personal, termasuk poligami, hukum fisik oleh suami terhadap istri, perceraian sepihak di luar hukum oleh suami, mas kawin, hak memelihara anak, tunjangan anak, hukum waris, tatacara berpakaian, dan akses perempuan ke ruang publik serta kantor umum, terutama kantor (atau jabatan) kepala negara. Yang lebih baru lagi, beberapa komunitas telah mulai mengangkat persoalan kepemimpinan ibadah, khususnya sebagai imam shalat berjamaah di hari Jum'at.

Tanggapan-tanggapan terhadap persoalan di atas bisa digolongkan menjadi:

\section{a. Tanggapan Apologi}

Tanggapan ini dimaknai bahwa Islam sebagaimana tersurat dalam Kitab Allah SWT dan contoh yang diberikan oleh Nabi memberikan semua hak yang di- 


\section{Rini Puji Astuti}

perlukan oleh kedua jenis kelamin manusia bagi kesejahteraan dan pemenuhan pribadi masingmasing.Tanggapan ini memuat dua perbedaan. Pertama, ada perbedaan yang tidak bisa dipungkiri antara kebutuhan dan keinginan laki-laki dengan kebutuhan dan keinginan perempuan yang dipahami dan dilayani oleh ayat-ayat dalam AlQuran. Kedua, praktik dalam berbagai komunitas Muslim menyalahi atau tidak memenuhi seluruh hak bagi perempuan sebagaimana telah tersurat dalam Al-Quran dan hadits.

b. Tanggapan Reformis

Bagi para Reformis, ajaran

Allah SWT telah disalahpahami secara tidak memadai dan/atau disalah artikan. Mereka menggunakan argument filosofis dan kontekstual untuk menafsirkan kembali ayat-ayat Al-Quran, hanya mereka lebih sadar akan kebutuhan untuk menafsirkan kembali sekaligus sadar akan keterlibatan diri mereka dalam kegiatan semacam itu sementara para Reformis dapat mempertanyakan atau menggugat tafsir tradisional, mereka tidak mempertanyakan keyakinan tradisional bahwa Al-Quran adalah ajaran Allah SWT sendiri, bukan buatan manusia.

\section{c. Tanggapan Transformatif Tanggapan ini berniat untuk} memperbaharui tradisi secara menyeluruh, selagi masih tetap berada di dalam kerangka kerja wacana Islami yang dirumuskan secara tradisional. Mereka menggunakan berbagai strategi untuk menciptakan ruang penafsiran dan untuk mempertemukan berbagai pertentangan yang muncul, hal-hal yang membingungkan, atau tegangantegangan di dalam teks itu.

d. Tanggapan Rasionalis

Salah satu feminis Rasionalis adalah Rifaat Hassan. Ia menyatakan bahwa karena Allah Maha Adil dan Maha Pengasih, 
Vol. 12, No. 2, Oktober 2019

p-ISSN:2086 -0749

e-ISSN:2654-4784

maka ajarannya hanya bisa ditafsirkan dalam istilah yang selaras dengan kualitas dimata Allah SWT. Pandangan tersebut berarti menerapkan kriteria keadilan kepada Al-Quran, dari pada sekedar menerima begitu saja bahwa Al-Quran pastilah adil. Atau, dalam mengambil pandangan tentang keadilan yang dikembangkan dalam sebagian ayat Al-Quran, serta menggunakannya untuk menilai ayat lain yang tampaknya mengguncangkan pandangan tentang keadilan itu.

e. Tanggapan Rejeksioni

Tanggapan ini merupakan tanggapan ekstrim yang rela mengorbankan nyawa mereka sendiri untuk menyatakan kewenangan Al-Quran dalam mendeskripsikan perempuan. Bagi mereka, titik pangkalnya adalah pengalaman perempuan, dan argumen apapun di luar itu, tak peduli dari manapun sumbernya, yang mendukung penindasan terhadap perempuan, akan ditolak.

Hanya saja, perlu diperhatikan bahwa perempuan boleh bekerja atau menjadi pemimpin dengan catatan:

1) Tidak meninggalkan tugas utamanya sebagai ibu

2) Mendapatkan izin dari suami

3) Tidak bekerja di tempat yang laki-laki dan perempuan saling berbaur

4) Tidak melakukan pekerjaan yang merusak kepribadian seorang muslimah

5) Senantiasa menjaga aurat dan kesucian dirinya.

Kepemimpinan perempuan dalam segala bidang kehidupan politik, ekonomi, sosial-budaya pada semua tingkat internasional, regional, nasional, masyarakat dan keluarga masih belum dapat 


\section{Rini Puji Astuti}

dikatakan mantap. Dalam banyak hal status perempuan dalam kehidupan sosial masih mengalami diskriminasi, perempuan kurang memperoleh akses terhadap pendidikan, pekerjaan, pengambilan keputusan dan dalam ranah publik lainnya. Keadaan ini menciptakan permasalahan sendiri dalam upaya pemberdayaan perempuan, dimana perempuan diharapkan memiliki peranan yang lebih kuat dalam memberikan kontribusi terhadap pembangunan. ${ }^{13}$

Hambatan lain yang sering dikutip untuk kemajuan perempuan adalah perbedaan gender yang diasumsikan ada dalam komitmen pada pekerjaan dan motivasi untuk memimpin. Klaim ini menegaskan bahwa laki-laki lebih mungkin memiliki sifat yang diperlukan untuk kepemimpinan yang efektif dibandingkan perempuan. Stereotip gender menggambarkan keyakinan yang bersifat pelabelan tentang sifat per-

${ }^{13}$ Suhandjati (2010), 14. empuan, dimana lakilaki dianggap memiliki karakteristik pengontrol, seperti keyakinan diri, ketegasan, kemandirian, rasionalitas, dan kepastian. Sementara itu, perempuan dianggap memiliki karakteristik sosial, seperti peduli kepada orang lain, peka, hangat, suka menolong, dan membimbing. ${ }^{14}$ Sehingga, hal ini akan menyebabkan penilaian yang bias terhadap perempuan, dimana perempuan dianggap tidak efektif dalam memimpin. Terlepas dari hambatan tersebut, perempuan menunjukkan jumlah yang lebih besar dalam posisi kepemimpinan puncak.

Dalam medan politik dan hukum, Imam Abu Hanifah memperkenankan perempuan menjadi pemimpin dalam hal-hal yang menjadi urusannya, yakni selain masalah pidana. Adapun Imam Thabari dan Ibnu Hazm memperbolehkannya menjadi pemimpin dalam bidang apapun. Hanya saja, perlu menjadi catatan

${ }^{14}$ Northouse (2013), 337. 
Vol. 12, No. 2, Oktober 2019

p-ISSN:2086 -0749

e-ISSN:2654-4784

bahwa perempuan boleh bekerja atau menjadi pemimpin dengan catatan tugas utamanya sebagai ibu tidak diabaikan, mendapatkan izin dari suami, tidak bekerja di tempat yang laki-laki dan perempuan saling berbaur, senantiasa menjaga aurat dan kesucian dirinya. ${ }^{15}$

Sejak abad 15 silam Islam, Al-Quran telah menghapuskan berbagai macam diskriminasi antara laki-laki dan perempuan, Al-Quran memberikan hak-hak kepada kaum perempuan sebagaimana hak yang diberikan kepada kaum laki-laki. Diantaranya adalah masalah kepemimpinan, Al-Quran memberikan hak kepada kaum perempuan untuk menjadi pemimpin, sebagaimana hak-hak yang diberikan kepada laki laki. Faktor yang dijadikan pertim-

15 Afra (2008), 345. bangan dalam hal ini hanyalah kemampuan dan terpenuhinya kriteria untuk menjadi pemimpin. Jadi, kepemimpinan itu bukan monopoli kaum laki-laki, tetapi bisa diduduki dan dijabat oleh kaum perempuan. ${ }^{16}$

Secara garis besar, teori gender dapat diklasifikasikan menjadi dua kelompok:

Pertama, kelompok teori nature yang mengatakan bahwa perbedaan peran laki-laki dan perempuan ditentukan oleh faktor biologis. Anatomi laki-laki, dengan sederet perbedaannya dengan perempuan, menjadi faktor utama dalam penentuan peran sosial kedua jenis kelamin tersebut. Lakilaki menjalankan peran utama dalam masyarakat karena secara umum dianggap lebih potensial, lebih kuat, lebih produktif. Di sisi 49.

${ }^{16}$ Huzaemah Tahido Yanggo (2010), 


\section{Rini Puji Astuti}

lain, organ reproduksi perempuan beserta fungsinya yang diasosiasikan kepadanya, seperti hamil, melahirkan, dan menyusui, dianggap membatasi ruang dan gerak perempuan. Batasan ini tidak berlaku bagi laki-laki. Perbedaan inilah yang melahirkan pemisahan fungsi dan tanggung jawab antara laki-laki dan perempuan. Termasuk dalam kelompok teori ini adalah teori fungsionalis struktural, teori sosio-biologis, dan psikoanalisis.

Kedua, kelompok teori nurture yang melihat bahwa perbedaan karakter dan peran sosial antara laki-laki dan perempuan lebih ditentukan oleh faktor sosialbudaya. Perspektif ini menyimpulkan bahwa pembagian kerja antara laki-laki dan perempuan dalam masyarakat tidak ditentukan oleh faktor biologis, tetapi dikonstruksikan oleh budaya, yakni relasi kuasa. Pandangan ini didukung oleh teori-teori konflik dan teori-teori feminis. ${ }^{17}$

\section{Simpulan}

Peningkatan keberdayaan perempuan dalam kepemimpinan efektif, tidak bisa terlepas dari kepemimpinan laki-laki, perbedaan kepemimpinan perempuan dan laki-laki antara lain: pemimpin wanita selalu lebih cenderung untuk bertingkah laku secara demokratik dan mengambil bagian dimana mereka lebih menghormati dan prihatin terhadap pekerjanya/bawahannya dan berbagi "kekuasaan" serta perasaan dengan orang lain. Gaya kepemimpinan ini dikenal sebagai kepemimpinan interaktif yang menekankan aspek keseluruhan dan hubungan baik melalui komunikasi dan persepsi yang sama. Secara perbandingan, pemimpin lelaki lebih cenderung ke arah kepemimpinan "tendency". Dengan cara ini mereka lebih ter-

${ }^{17}$ Ema Marhumah (2011), 4-5. 
Vol. 12, No. 2, Oktober 2019

p-ISSN:2086 -0749

e-ISSN:2654-4784

arah untuk tetap terjaga dan berkelakuan secara "asertif".

Gaya kepemimpinan perempuan lebih cenderung melakukan pendekatan yang mengajak bawahan untuk ikut maju berkembang dalam pemikiran dan pemimpin ikut terjun di dalam melaksanakan tugas agar mencapai tujuan, sedangkan berbeda dengan kaum laki-laki yang memiliki gaya kepemimpinan yang cenderung hanya hubungan atasan dan bawahan yang dimana bawahan melakukan apa yang diperintahkan oleh atasan tanpa adanya pendekatan emosional antara bawahan dan atasan.

Secara umum, gaya kepemimpinan lelaki dan wanita adalah sama tetapi situasinya yang akan mungkin berbeda. Penelitian dilakukan di Amerika serikat, mendapati bahwa pemimpin lelaki lebih berkesan di dalam organisasi ketentaraan, sementara wanita dalam organisasi pendidikan dan sosial. Kepemimpinan perempuan tidak hanya terbatas dalam kehidupan rumah tangga, tetapi juga dalam masyarakat. Kepemimpinannya tidak hanya terbatas dalam upaya mempengaruhi kaum lelaki agar mengakui hak-haknya yang sah, tetapi juga harus mencangkup sesama jenisnya agar dapat bangkit bekerja sama meraih dan memelihara harkat dan martabat mereka, serta membendung setiap upaya dari siapapun, baik laki-laki maupun perempuan, kelompok kecil atau besar yang bertujuan mengarahkan mereka ke arah yang bertentangan dengan harkat dan martabatnya.

\section{Daftar Pustaka}

Abdul Wahid, Wawan Gunawan "Membaca Kepemimpinan Perempuan dalam RUU Kesetaraan dan Keadilan Gender dengan Perspektif Mubam- 


\section{Rini Puji Astuti}

madiyah" dalam Jurnal $M u$ sawa, Vol. 11, No. 2 (Juli, 2012).

Bush, Tony, Educational Leadership and Management: Theory, Poliy, and Practice Johabbesburg: MGSLG Press, 2006).

Bronznick, Shifra, 21st Century Women's Leadership (diakses melalui

www.wanger.nyu.edu/leade rship pada 3 Juli 2014).

Ibtibsyarah, Makalah "Hak Politik

Perempuan dalam Perspektif

Islam; Kajian Tafsir Maudhu'i” dipublikasikan oleh Dirjen Pendidikan Islam

Kementrian Agama RI. (diakses melalui www.dipertais.net).

Ihromi, Kiprah Perempuan (Yogyakarta: 1995).

James A. Lee dalam "Management Theories and Prescriptions" Jamhari, (2003).

Joewono, Kepemimpinan (Yogyakarta: 2002).

Linda Coughlin, et all, Enlighted Power; How Women Are Transforming The Practice of Leadership (San Fransisco; Jossy Bass, 2005).
Littlejohn \& Foss, Teori Komunikasi (2009).

Mansur, Abdul Qadhir, Kepemimpinan Perempuan (Yogyakarta: 2005).

Mubin, Kepemimpinan Persamaan Gender (Yogyakarta: Penerbit Andi, 2008).

Muslikhati, Kepemimpinan Perempuan dalam Peran Gender (Yogyakarta: 2004).

Nawawi, Tipe Kepemimpinan (Yogyakarta: 1993).

Nurul, Kepemimpinan Perempuan (Yogyakarta: Penerbit Andi, 2008).

Ponty, Merleau Maurice, Phenomenology of Perception, Taylor and Francis e-library.2005

Ralp M. Stogdill dalam "Personel Factor Associated With Leadership” yang dikutip oleh Suhandjati (2010).

Republika.com www.republika.co.id/berita /dunia-islam/fatwa/ 11/06/20/ (diakses pada 3 Juli 2014).

Sarbin \& Allen dalam Eagly et al., Buku Sosial (Yogyakarta: 2003). 
An-Nisa' : Jurnal Kajian Perempuan \& Keislaman

Vol. 12, No. 2, Oktober 2019

p-ISSN:2086 -0749

e-ISSN:2654-4784

Scurzer Firozza, Critical Feminist

Studies in Religion Florida,

(SAGE Publication, 2013).

Situmorang, Nina Zulida, "Gaya

Kepemimpinan Perempuan" da-

lam Proceeding PESAT

Universitas Gunadarma,

Vol. Oktober 2011).

Suwondo, Nani, Kedudukan Wanita

Indonesia dalam Hukum dan

Masyarakat (Jakarta: PT

Gramedia, 1991)

Tan, Kepemimpinan Perempuan yang

Efektif (Yogyakarta: 1996).

Tim Majelis Tarjih, Tanya Jawab Agama (Yogyakarta: Suara Muhammadiyah, 1998).

Torang, Tipe Kepemimpinan (Yogyakarta: 2013). 